\title{
Morphology of sodium salt of calf thymus DNA on mica, alumina, and silica surfaces: Effect of solvent and drying method
}

\author{
Senem Yetgin ${ }^{a}$ and Devrim Balköse ${ }^{b}$

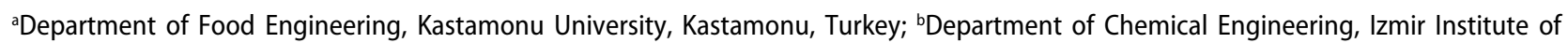 \\ Technology, Izmir, Turkey
}

\begin{abstract}
Investigation of morphology of deoxyribonucleotide triphosphate (DNA) dried on different surfaces by atomic force microscopy (AFM) is important in DNA research that is focused on subjects of condensation for gene therapy, sizing, DNA mapping, and cancer examination. The solvent, the surface type, and the method of drying effect the morphology of DNA on solid surfaces. Ethanol and water were used as solvents, flat mica, silica, and alumina surfaces were used as the substrates in the present study. Different methods such as ambient air-drying, $\mathrm{N}_{2}$-forced flow regime drying, and freeze-drying have been applied to droplets of DNA solutions in water or ethanol on the substrates. Forced flow drying regime causes nonlinear DNA attachment on the surface and selfassembly. DNA vertical distance on mica surface was found to be 6 and $1.4 \mathrm{~nm}$ for DNA dried in ambient air from ethanol and water solutions, respectively. It was $1.6 \mathrm{~nm}$ for $\mathrm{N}_{2}$ flow drying of aqueous DNA solution on mica surface. It was $4.6,4.6$, and $1.99 \mathrm{~nm}$ for ambient, $\mathrm{N}_{2}$ flow, and freeze-dried aqueous DNA on alumina surfaces, respectively. Aqueous solution of DNA dried under $\mathrm{N}_{2}$ flow on silica surface had $0.8 \mathrm{~nm}$ vertical distance. The smallest standard deviation of $0.05 \mathrm{~nm}$ was observed for DNA dried under $\mathrm{N}_{2}$ flow on alumina surface.
\end{abstract}

KEYWORDS

AFM; alumina; DNA; drying; mica; silica; solvent

\section{Introduction}

Deoxyribonucleotide triphosphate (DNA) is a biological polymer that stores genetic information in almost all living organisms. Its visualization is important in the case of understanding the interactions with the surface. DNA consists of two strands where the sugar and phosphate are the rails, and the base pairs are the rungs. The rails run in opposite orientation to each other. On the outside of the helix structure, there is a space between the turns of the phosphate groups; these are termed grooves. There are three types of DNA double helices, i.e., A-type, B-type, and Z-type. Watson-Crick structure is also referred to as B form DNA, or B-DNA. Kistner and coworkers reported that DNA is mainly in the $\mathrm{B}$ form in aqueous solution ${ }^{[1]}$ and at low ethanol concentrations, DNA is entirely soluble and is in still B form. ${ }^{[2]}$

Ethanol is the solvent used in DNA precipitation in molecular biology laboratories for several molecular biology and analytical chemistry experiments. ${ }^{[3]}$ The alcohol content in solution reduces the multivalent cation concentration and finally DNA condenses, ${ }^{[4]}$ since it is known that aliphatic alcohols are interceptors of $\mathrm{OH}$ radicals. $^{[5]}$ On the other hand, high salt content decreases the ethanol impact on DNA. Meanwhile, it is known that the $\mathrm{B}-\mathrm{A}$ transition is higher with an increase in the concentration of ethanol. ${ }^{[6]}$ The persistence lengths decrease linearly as the concentration of ethanol increases in ethanol water solutions. However, when the ethanol concentration is higher than $92 \%$, DNA transforms to $\mathrm{P}$ form. The $\mathrm{P}$ form is thought to have altered secondary structure with the almost complete absence of hydrogen bonding and base stacking, while the tertiary structure is condensed. ${ }^{[2]}$ The adsorption of DNA from aqueous solutions on powder surfaces is an important process for DNA purification and DNA transfer. The aggregation state of DNA in water is important in adsorption process. Highly polymerized calf thymus can be dissolved in water and the dissolved DNA particles can be observed by drying the DNA solution droplet on a wafer surface.

DNA from calf thymus at different lengths is available for adsorption studies. While DNA with approximately 2,000 double-stranded base pairs was used for adsorption on mesoporous silica, ${ }^{[7]}$ native calf thymus double-stranded DNA (23,000 bp, A260/A280> $1.8)$ was used for imaging it on a graphite surface. ${ }^{[8]}$

High-resolution imaging by atomic force microscopy (AFM) of inorganic particles ${ }^{[9]}$ and biological samples

CONTACT Senem Yetgin senemyetgin@gmail.com Department of Food Engineering, Kastamonu University, Kastamonu 37 000, Turkey. 
such as DNA, proteins, bacteria, cell membranes has been the main motivation of inorganic and biologic research. ${ }^{[2]}$ AFM is used to examine the solid bridges formed between two spray-dried sodium carbonate particles by Leaper et al. ${ }^{[9]}$

Recently, nanomechanical and nanoadhesive properties of the samples was measured for detection of cancer cell using the AFM as a microreological device as force machine. The number of research articles subject to this characterization technique is increased exponentially. ${ }^{[10]}$ High-resolution images of DNA, proteins, and polymers have been obtained in air and liquids after invention of this technique. ${ }^{[11-14]}$ Samples have to be dried in conditioned air before imaging procedure. Biological structures can be observed in their original form in buffer solution by AFM. However, AFM technique is used with completely dried sample, especially for tapping and contact mode. The 15\% of published articles on AFM of DNA was related with imaging under aqueous media. ${ }^{[15]}$

There are many studies on drying of water droplets with nanoparticles in air ${ }^{[16]}$ or water droplets on different surfaces. ${ }^{[17]}$ The morphology of a droplet during drying is mostly affected by the porosity and the strength of the shell formed by the nanoparticles, and primary particle size of the nanoparticles in the solution. ${ }^{[16]}$ Lee et al. ${ }^{[17]}$ proposed an evaporation model to analyze the drying of sessile water droplets on LCD panels with IR lamps by including reflection on the substrate and changes in the contact angle between a water droplet and the substrate. The heat transfer mechanisms during the evaporation process of water droplets on glass and copper substrates in terms of latent energy, radiation energy, and conduction energy were found to be different. The heat conduction between the water droplet and the copper substrate played a major role in the beginning of the evaporation, resulting in longer evaporation times due to heat loss. ${ }^{[17]}$ A water droplet having DNA should be dried on the surface of substrates to record its image by AFM. The suitable substrates for AFM, DNA solution concentration effect on the morphology of dried DNA, details of tapping and phase image by AFM, and drying methods are summarized as follows.

\section{Suitable substrate for AFM}

Preparing samples for AFM-supported material seems to be not important; but if it has an interaction with sample, it will change everything. An atomically flat substrate is usually required for high-resolution work, and for looking at individual molecules. The first problem is choosing a suitable substrate. ${ }^{[1]}$ To be able to examine biological structures in their original form, these must be well attached to a solid substrate to resist the forces applied by the scanning tip. Furthermore, smooth surface is the condition for sample holder. Mica is useful as an AFM substrate because it is atomically flat, with a layer height of $0.37 \pm 0.02 \mathrm{~nm} .{ }^{[18]}$

Surface charge has also explained interaction between sample and support in the case of ionic attraction. Consequently, isoelectric point of zero charge (IEP) is important. In the literature, isoelectric points of silica and alumina sapphire single crystals were reported to be $\mathrm{pH} 2^{[19]}$ and $\mathrm{pH} 5.2,{ }^{[20]}$ respectively. In addition, mica is a layered mineral with point of zero charge of $\mathrm{pH} 2 .{ }^{[21]}$

Surprisingly, one of the commonly used substrates for AFM imaging of DNA or RNA is negatively charged mica. ${ }^{[22]}$ DNA is normally negatively charged due to its phosphate groups in the backbone. Divalent cations are used to link them to the negatively charged mica surface. It was found that DNA could tightly bind to mica with suitable solution concentrations of $\mathrm{Ni}^{+2}$ and, $\mathrm{Co}^{2+}$, or $\mathrm{Zn}^{2+}$ ions. Diffusion was related to the number of divalent cations per base pairs that participate to the counterion correlations. ${ }^{[23]}$ Therefore, theoretical and experimental evidence are consistent to those transition metal cations $\left(\mathrm{Ni}^{2+}, \mathrm{Cu}^{2+}\right.$, etc.), for which DNA molecules bind strongly to mica. Nevertheless, other divalent metal ions such as $\mathrm{Mg}^{2+}, \mathrm{Ca}^{2+}, \mathrm{Cd}^{2+}$, or $\mathrm{Hg}^{2+}$ cannot bind DNA to mica tightly or cannot bind DNA. ${ }^{[2]}$ They provided a reasonable explanation for these observations. The ions with large ionic radii cannot fit into the mica cavities and therefore cannot bind DNA to mica. The divalent metal ions react with the hydroxyl groups in the "cavities" of mica surface. However, narrow ionic strength conditions are often required for adsorption, suggesting a more complex mechanism. Also, the adsorption of plasmid DNA molecules onto untreated cleaved mica instead of treated one from a solution containing $\mathrm{Mg}^{2+}$ or $\mathrm{Ca}^{2+}$ was identified as easy and repeatable. ${ }^{[24]}$

Muscovite mica, $\mathrm{KAl}_{2}(\mathrm{OH})_{2} \mathrm{AlSi}_{3} \mathrm{O}_{10}$ which is a nonconducting layered mineral, offers an excellent property being a substrate. The mica surface has silicon, oxygen, and aluminum atoms surrounding hydroxyl groups that are near below the surface. ${ }^{[25]}$ Mica is the most frequently used substrate for imaging biological specimens, including double-stranded DNA. Mica can be easily prepared for imaging by cleaving the top layer off with tape. It is atomically flat, clean after cleavage, easy to cut to desired sizes, relatively inexpensive and negatively charged. Feng and coworkers ${ }^{[26]}$ reported that four single strands of calf thymus DNA were self-assembled to a network structure with $2.2 \pm 0.01 \mathrm{~nm}$ height on mica surface. 


\section{DNA concentration for AFM imaging}

Biomaterial containing solution is generally transferred onto AFM substrate as a drop. The solvent is evaporated to obtain the biomaterial on the surface. Surface dynamic forces play an important role on the morphology of the dried biomaterials. Fang and coworkers $^{[27]}$ studied evaporation kinetics of droplets containing DNA, as a function of DNA concentration (0.5-500 $\mathrm{ng} / \mu \mathrm{L})$ by confocal fluorescence microscopy at $25^{\circ} \mathrm{C}$ and at $36 \pm 2 \%$ humidity. Measurements of the droplet contact angle, height, and base diameter revealed two modes, which were distinct only for very low or very high concentrations. For low concentrations, the DNA chains were distributed in isolated patches along the liquid-vapor interface of the droplet. For high concentration of DNA in droplets, the liquid surface was covered with a solid shell of DNA. It was shown that the concentrated DNA was localized at the edges of the drying droplet. This phenomenon which is called as the "coffee ring effect" could be avoided by drying under ethanol vapor atmosphere. ${ }^{[28]}$

\section{Tapping mode and phase image in AFM}

In the AFM technique, the tip is excited into a sinusoidal oscillation at a particular frequency using the tapping (intermittent contact) mode. As the sample is scanned, not only will the cantilever deflection amplitude change as the forces encountered by the tip change, but the cantilever will generally oscillate at a frequency that lags that of the excitation force (the force from the piezo-stack to which the cantilever/tip assembly is attached). There will be some relationship between phase lag and the properties of the sample surface encountered by the tip. ${ }^{[29]}$ Phase angle contrast is a stronger function of viscoelastic properties with increasing free amplitude or set point. However, the effect of adhesion on phase angle contrast becomes more dominant at low free amplitudes or set points. ${ }^{[29]}$

\section{Drying methods}

Investigated sample can be dried by different methods such as under air, nitrogen flow regime by forced mass transfer, and freeze-drying procedures under vacuum condition. Researchers generally chose drying under ambient condition which is the easy way for preparation of AFM sample for tapping and contact modes. Samples are generally immobilized onto surface when imaged under air; if not it would have some problems. It was reported that air-dried DNA kept its native 3D structure during dehydration in air. ${ }^{[30]}$
In ambient air, the rate of drying is lower than that of forced convection drying under a flow regime in which the evaporated molecules from the surface are carried away by the flowing gas. In ambient air, the solid surface is covered by saturated water vapor making the mass transfer slower and the DNA find sufficient time to relax to more stable conformations. In flow regime, due to fast drying DNA is expected to keep its original conformation since the time is shorter than needed for its relaxation.

In conventional drying, liquid water is evaporated from the pores of the solid. The interfacial tension between liquid water and solid is very high for small capillaries. As the water evaporated by conventional drying, the walls of capillaries become closer to each other by the interfacial tension and the solid is agglomerated. The surface tension can be reduced by freeze-drying under vacuum. In freeze-drying, the solid water is sublimed. The interfacial tension between solid walls and the solid water is much smaller. If the water is sublimed from ice present in the capillaries, the forces attracting the capillary walls together is small and the solid is not agglomerated and it keeps its original form. Freeze-dried biomacromolecules keep their hydration layer so they remain stable. ${ }^{[24]}$ Atmospheric freezedrying can be used in combination with heat pumps instead of vacuum freeze-drying. Claussen et al. ${ }^{[31]}$ reported that atmospheric freeze-drying has a relatively long residence time because of internal resistance to mass transfer. In combination with heat pump technology, atmospheric freeze-drying seems to be an environmentally friendly and economically favorable technology compared to vacuum freeze-drying.

This study aims at imaging highly polymerized calf thymus DNA in air media on bare mica, alumina, and silica substrates that are not surface functionalized to elucidate the mechanism of adsorption of DNA on their surfaces. Ethanol and water were used as the solvents. Different drying methods were applied to DNA solution droplets on different surfaces for this purpose.

\section{Materials and methods}

Sodium salt of highly polymerized DNA from calf thymus (Sigma Aldrich) was used as received. This type of calf thymus DNA is also suggested by the producer company in physicochemical studies of DNA behavior in solution without any salt contributing factor. Morphology of DNA samples was examined by electron microscopy with FEI Quanta FEG-250 instrument. The samples were gold coated before the experiments.

Freshly cleaved mica with $9.9 \mathrm{~mm}$ diameter (Ted Pella), silica wafer polished in c plane (0001) 
(CS analytic company), and alumina wafer polished in (0001) plane (MTI corporation) were used as substrates in AFM experiments. The alumina and silica surfaces were all cleaned by serial and repeated widespread process before each test. This cleaning process cycle included sonication in pure water (quality of up to $0.055 \mu \mathrm{S} / \mathrm{cm}$ ) then ethyl alcohol for 15 -min periods with subsequently $20 \mathrm{~min}$ of radiation with UV to remove remaining surface contaminants. Finally, this cycle was completed with drying under $\mathrm{N}_{2}$ flow regime. Mica disk was just exposed to the UV light for each analysis after it had been cleaved from the top layer off with a scotch tape. Furthermore, all the equipment were exposed to a short range UV light for $20 \mathrm{~min}$.

DNA fibers cut into 1-3- $\mu$ m-length pieces using a sharp and sterile scissors were used in the preparation of its solutions in ethanol and water. DNA dissolved in ethanol and ultrapure water $(\mathrm{pH} 7-0.055 \mu \mathrm{S} / \mathrm{cm})$ at $100 \mathrm{ng} / \mu \mathrm{L}$ concentration was transferred on the substrates and was dried. DNA in ethanol solution was dried on mica surface only by conventional drying and DNA in water solution was dried on mica, silica, and alumina surfaces by conventional, forced convection, and freeze-drying. No buffer or salt was present in the solutions to avoid interference of AFM image by salt formation. Then, $2 \mu \mathrm{l}$ of $100 \mathrm{ng} / \mu \mathrm{l}$ of calf thymus DNA solution was placed onto the surface of the substrate using a micropipette. DNA solution droplet on the surface of each substrate was dried with three different methods as illustrated in Fig. 1.

The first method which was called as "ambient airdrying" was normal drying at $25^{\circ} \mathrm{C}$ in a closed Stuart orbital incubator (SI500) with $10 \mathrm{dm}^{3}$ volume at least for $15 \mathrm{~h}$.

The second method which was called as " $\mathrm{N}_{2}$ flow regime" was drying by forced convection under nitrogen flow at $25^{\circ} \mathrm{C}$. Nitrogen-forced flow regime drying procedure was performed for the surface of mica and silica, alumina wafers. A $2 \mu \mathrm{l}$ of $100 \mathrm{ng} / \mu \mathrm{l}$ of calf thymus DNA was placed onto the surface. The sample droplet was transferred to the wafers at room temperature and then compressed nitrogen gas was applied to the sample with the direction of gas flow at nearly an angle of $\sim 45^{\circ}$ as illustrated in Fig. 1. Distance between gas source and sample was carefully controlled to keep the interface in stable condition. The gas stream was kept in the same condition for one more minute after the drop was disappeared to ensure that the sample was completely dried.

The third drying method was "freeze-drying." The substrates having DNA solution drops were placed in vials containing $1 \mathrm{~cm}^{3}$ frozen water. The vials were placed in freeze-drying equipment (Labconco Free Zone-4.5) and the drying was performed at $-51^{\circ} \mathrm{C}$ under vacuum till all the frozen water was evaporated.

The AFM, Digital Instruments MMSPM Nanoscope IV, was used in the tapping mode to obtain the twoand three-dimensional surface topology, and phase information of the surfaces in air. For imaging in air, Veeco RTESP tips were used. The tips had anisotropic geometry, with tip height $15-20 \mu \mathrm{m}$ and tip radius less than $10 \mathrm{~nm}$. The spring constant of the cantilever was $40 \mathrm{~N} / \mathrm{m}$. The nominal length and width of the cantilever beam were 125 and $35 \mu \mathrm{m}$, respectively. The typical tapping frequency was $263-291 \mathrm{kHz}$, the scanning rate was $1.0 \mathrm{~Hz}$, and scan angle was zero degrees. High free amplitude was used in obtaining the images. Thus, the lighter regions in the phase images represent more viscoelastic regions of the surface.

Clear AFM images were obtained since there were no salts in DNA solution transferred to wafers. If there were salts, the AFM tip would be interfered and the accuracy of the height measurements would decrease.

\section{Theory/calculation}

The images of dried DNA on the surfaces were examined with Nanoscope software with measuring the section analysis. Distributions of obtained vertical distance (y) of the DNA assemblies were fitted with Gaussian probability distribution, $p(y)$, as seen in Eq. (1):

$$
p(y)=\frac{1}{\sigma \sqrt{2 \pi}} e^{-\left(\frac{y-\mu}{2 \sigma^{2}}\right)^{2}}
$$

where $\mu$ is the mean of distribution, $\sigma$ is the variance of the distribution, and $y$ is the vertical distance of calf thymus DNA on the surface.

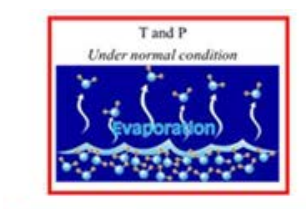

in ambient air

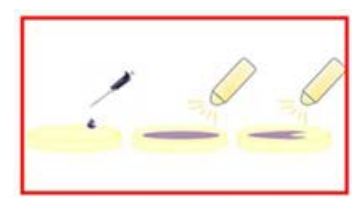

with $\mathrm{N}_{2}$ Flow Regime

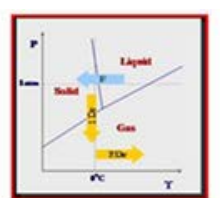

with Freeze Dryer

Figure 1. Schematic representation of used drying methods. 
In addition, it should be noted that vertical distance values $(y)$ were taken at least 90 domains for different drying methods for mica, silica, and alumina surfaces.

\section{Results}

\section{Morphology of DNA sodium salt as received}

The morphology of sodium salt of DNA as received is seen in SEM micrographs in Fig. 2. It is in the form of helical continuous fibers formed by winding of many DNA molecules. The average diameter of the fibers was $0.15 \pm 0.05 \mu \mathrm{m}$. The length of the fibers was longer than $300 \mu \mathrm{m}$. The fibers were much longer $(>300 \mu \mathrm{m})$ than expected $(9.5 \mu \mathrm{m})$ for DNA with 28,000 base pairs with $0.34 \mathrm{~nm}$ rise per turn of the helix. Thus, short DNA molecules were self-assembled by winding onto each other to form the long fibers. For preparation of DNA solutions in ethanol and in water, the fibers were cut into small pieces with a sterile tweezers. It was expected that DNA will disperse in ethanol without any change in its aggregation state and in water it will be separated into its single molecules by unwinding process of the fibers.

\section{Morphology of Na-DNA on mica by ambient air-drying of ethanol solution}

DNA particles in helical structure were dispersed evenly on mica surface as seen in phase image in Fig. 3. The average length and diameter of the fibers was $0.635 \pm 0.269 \mu \mathrm{m}$ and $0.109 \pm 0.027 \mu \mathrm{m}$ as shown in Figs. 4 and 5, respectively. The average pinch distance of the helical structure was $0.127 \pm 0.027 \mu \mathrm{m}$. The distance between the fibers was $0.645 \pm 0.463 \mu \mathrm{m}$ in horizontal direction as seen in Fig. 3. The surface tension of ethanol and water are 22.39 and $72.86 \mathrm{~m} \mathrm{Nm}^{-1}$, respectively. Thus, during drying in ethanol, the attractive forces pulling particles together is much smaller than drying in water. Thus, the fibers were attached to mica surface with even distances from each other in ethanol. The Marangoni effect ${ }^{[28]}$ also supports the even dispersion of particles during drying in ethanol.

DNA was dissolved in ethanol and dried in air on mica surface. Figure 6 illustrates calf thymus DNA image on mica with pure ethanol used as solvent. An average height of DNA taken with least 50 domains is $6 \mathrm{~nm}$. The higher width than the height of the fibers indicated strong interactions between the fibers and the surface.

\section{Ambient air-drying of aqueous DNA solution on different surfaces}

Zeta potential measurement showed that calf thymus DNA isoelectric point is at nearly $\mathrm{pH} 2.2 .^{[32,33]}$ Mica is a layered mineral with point of zero charge of $\mathrm{pH}$ 2. Thus at the $\mathrm{pH} 7$ of adsorption, both mica surface and DNA were negatively charged DNA was adsorbed on mica surface since there were attractive forces due to sharing of the counterions of the mica with DNA. However, DNA molecules appeared to have cross-links between them due to intermolecular attractions as seen in Fig. 7. It is clearly seen that the mica substrates was covered by a two-dimensional network of DNA structures as observed by Feng et al. ${ }^{[26]}$ The vertical distance distribution for DNA on mica is shown in Fig. 8. The average vertical distance $(1.4 \pm 0.1 \mathrm{~nm})$ was observed in the present study comparable to the one (2.2 \pm $0.01 \mathrm{~nm}$ ) observed by Feng et al. ${ }^{[26]}$ for calf thymus DNA on mica surface. However, the mesh size

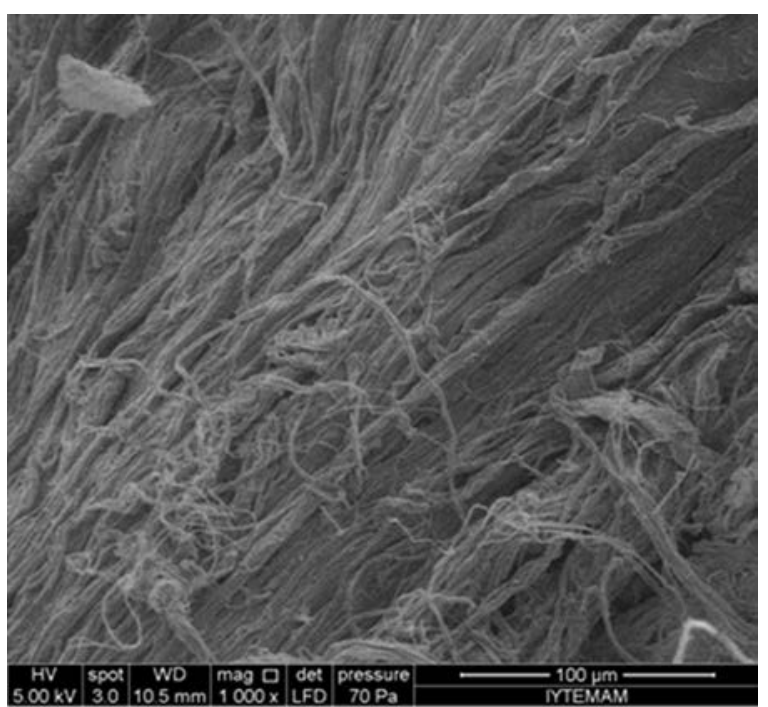

(a)

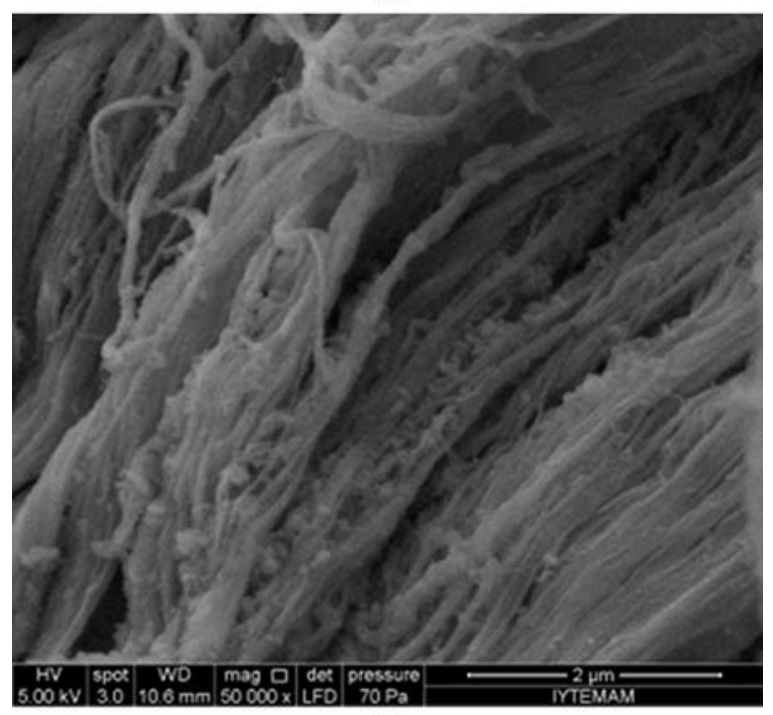

(b)

Figure 2. The SEM micrographs of sodium salt of calf thymus DNA as received: (a) 1,000 $\times$ and (b) 50,000 $\times$ magnification. 

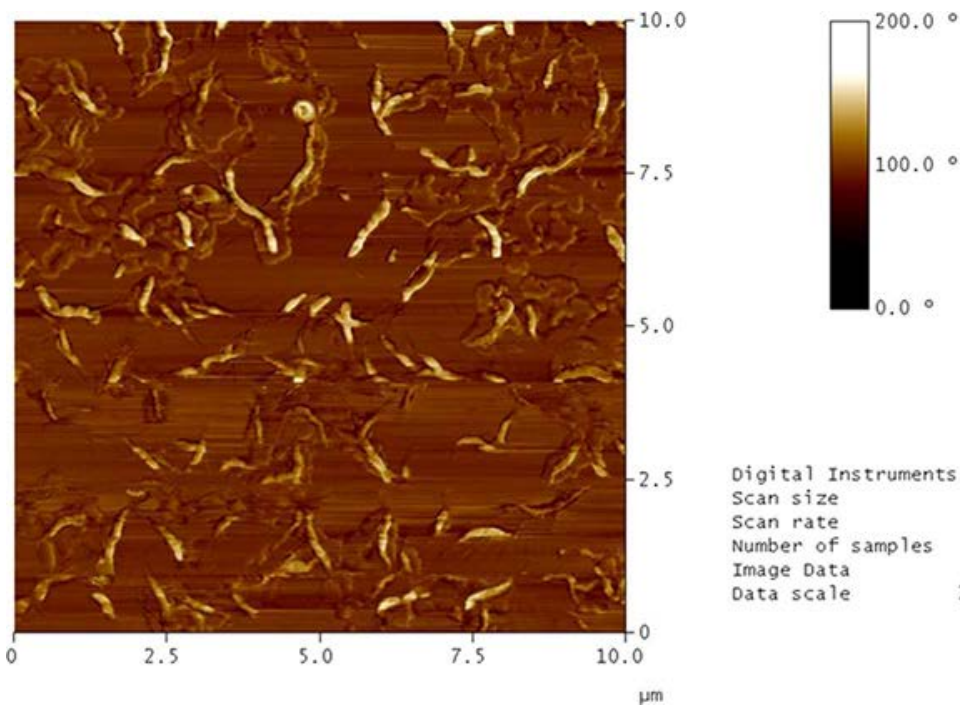

Figure 3. The phase image of DNA dissolved in pure EtOH at $100 \mathrm{ng} / \mu \mathrm{l}$ and dried in ambient air on mica.

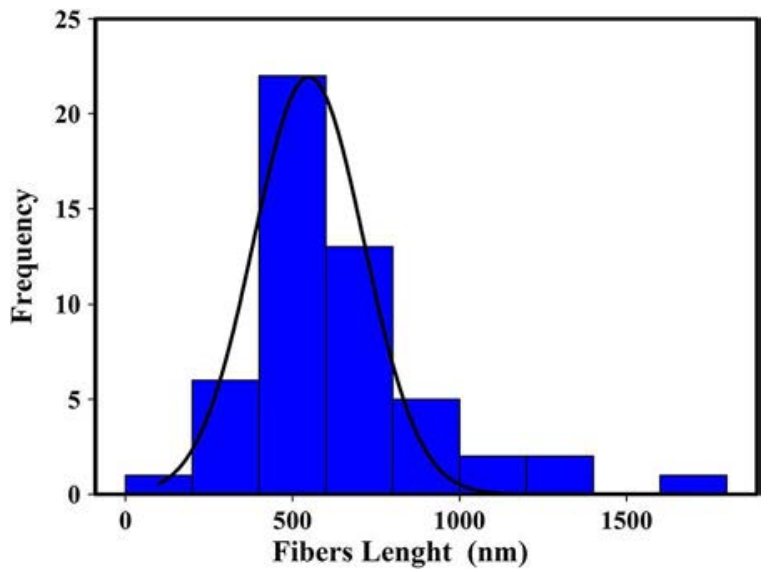

Figure 4. Gaussian distribution of length of the DNA fibers on mica surface from ethanol solution.

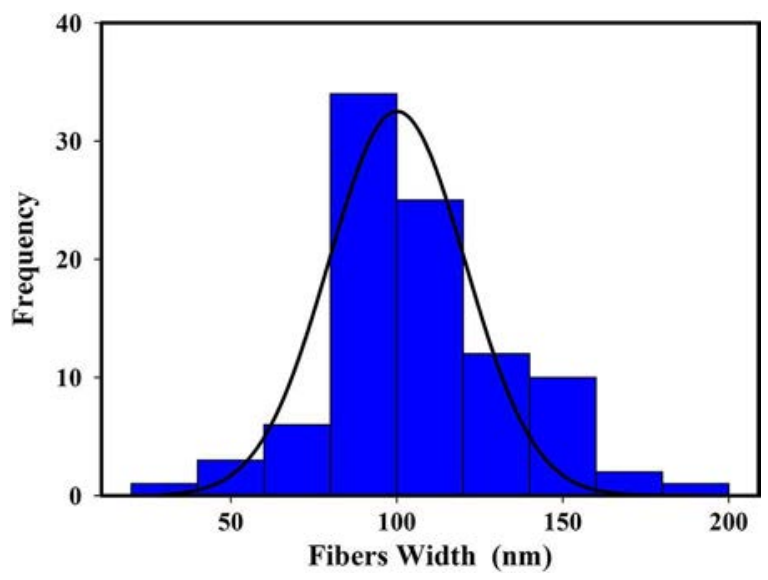

Figure 5. Gaussian distribution of width of the DNA fibers on mica surface from ethanol solution.
$(0.30 \pm 0.04 \mathrm{~nm})$ and fiber diameter $(0.03 \mathrm{~nm})$ of the network of DNA observed by Feng et al. ${ }^{[26]}$ were much smaller than those observed $(0.26 \pm 0.04 \mu \mathrm{m}, 0.05 \mu \mathrm{m})$ in the present study. This indicated that the DNA was at a much higher aggregation state in the present study. Similar network structures were observed in water-mica system without any DNA. ${ }^{[32]}$ Network of interconnected water channels formed after $5 \mathrm{~s}$ of contact of the tip at $40 \% \mathrm{RH}$, with a partially contaminated mica surface. The contamination is the result of exposure to the ambient air for $2 \mathrm{~h}$. Many angles between the segments were close to $120^{\circ}$. The extent of these channel structures increases with contact time of the tip with the surface at $40 \% \mathrm{RH}$. This was another manifestation of the angular epitaxy between the water structures and the mica lattice. ${ }^{[34]}$ Since a similar network structure was observed for both DNA-mica system ${ }^{[26,33]}$ and water-mica system, ${ }^{[34]}$ the attraction forces between

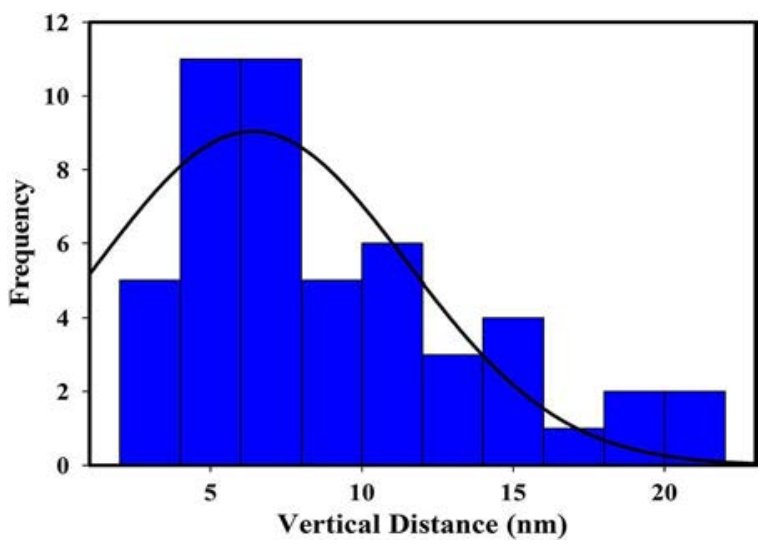

Figure 6. Gaussian distribution of the vertical height of DNA dissolved in ethanol and dried in air on mica surface. 

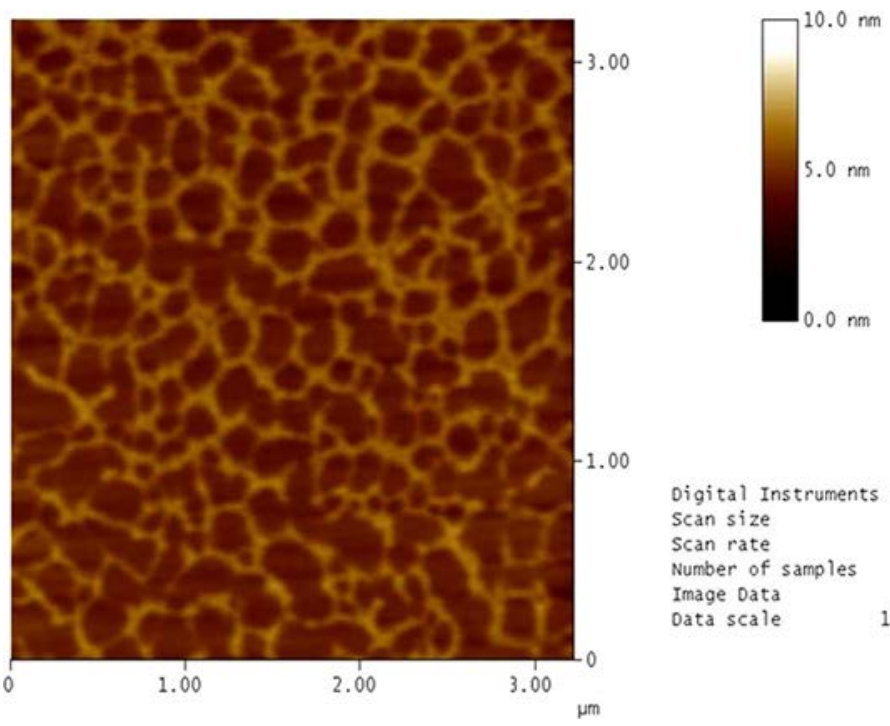

Figure 7. AFM image of DNA dried in ambient air on mica surface.

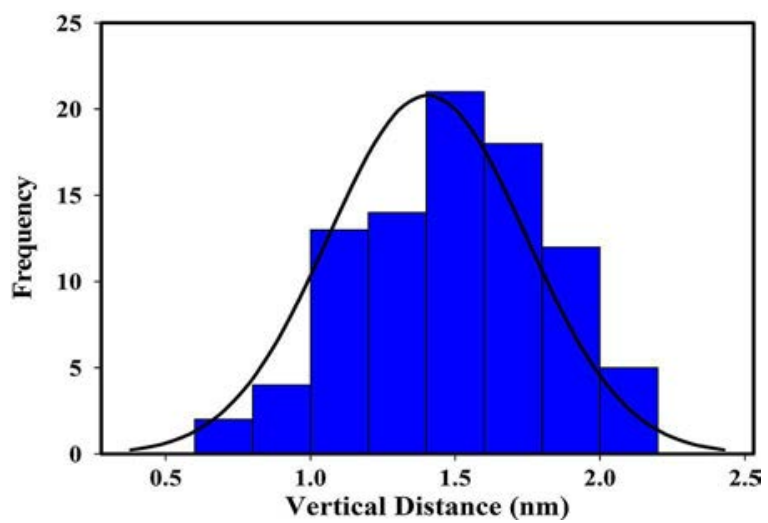

Figure 8. Gaussian distribution of AFM image DNA dried in ambient air on mica surface. water and mica should be governing this network structure in the present study.

Calf thymus DNA dissolved in pure water and dried on silica surface is seen in Fig. 9. Section analysis and surface plot from $5 \times 5 \mu^{2}$ scans were determined.

Highly polymerized DNA was assembled in rod-like shape on the silica surface as it was on mica surface. Using the Nanoscope IV software, the average distance between the fibers and the average height of the selected three lines were found as $686 \mathrm{~nm}$ and $1.8 \mathrm{~nm}$, respectively.

DNA has a high density on the alumina surface as seen in the phase image in Fig. 10. The phase image had sharper contrast than tapping mode for alumina surface. A monolayer of DNA particles observed on DNA structure on alumina surface is different from

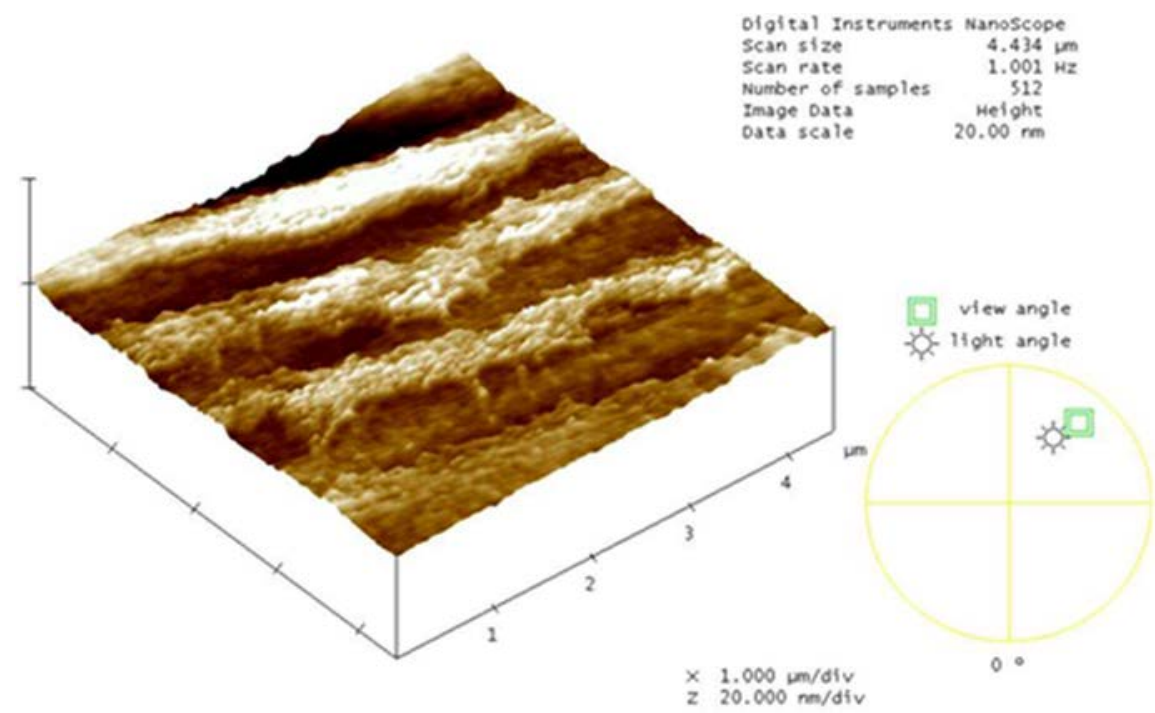

Figure 9. AFM image of DNA dried in ambient air on silica surface. 

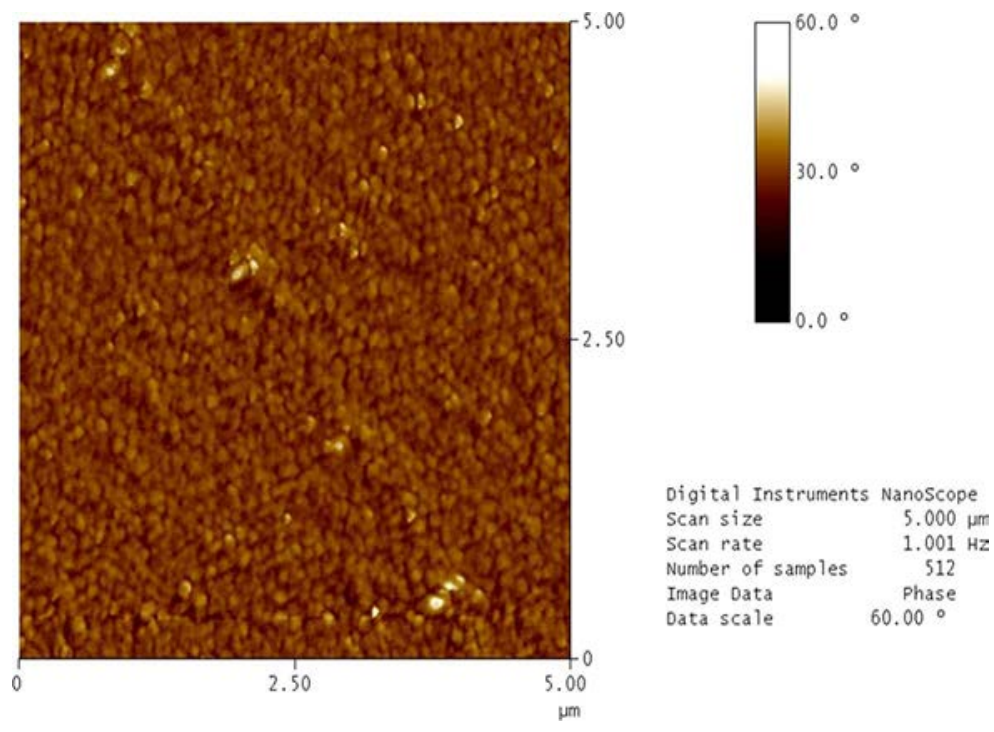

Figure 10. AFM image of DNA dried in ambient air on alumina surface.

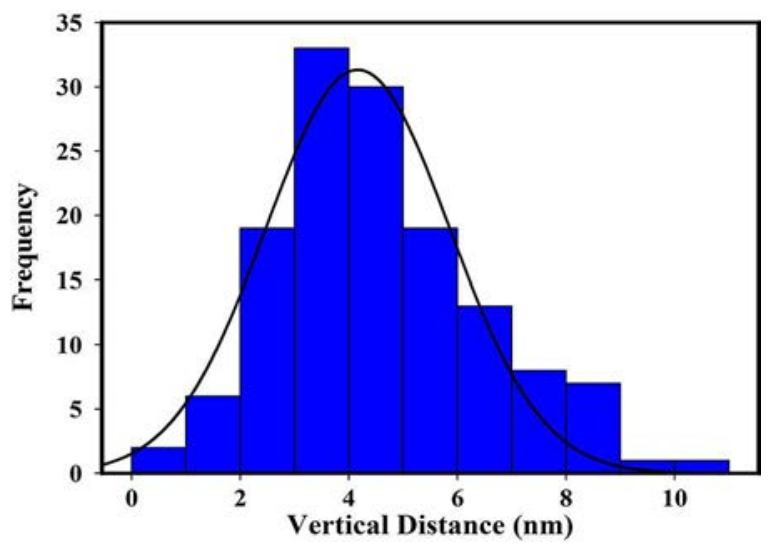

Figure 11. Gaussian distribution of AFM image of DNA dried in ambient air on alumina surface.
DNA on mica surface (Fig. 7). The particles of $80 \pm 2 \mathrm{~nm}$ diameter were arranged in a regular order, as superhelical fibers laid parallel to each other on the alumina surface. The high surface tension of water attracted the DNA particles to each other and they covered the surface evenly. The average vertical distance of DNA on alumina was determined to be $4.6 \mathrm{~nm}$ from tapping mode image as seen in its Gaussian distribution in Fig. 11.

\section{$\mathrm{N}_{2}$ flow regime drying and freeze-drying of aqueous DNA on different surfaces}

Results for other drying processes of $\mathrm{N}_{2}$ flow regime and freeze-drying have different effects on calf thymus DNA surface coverage.
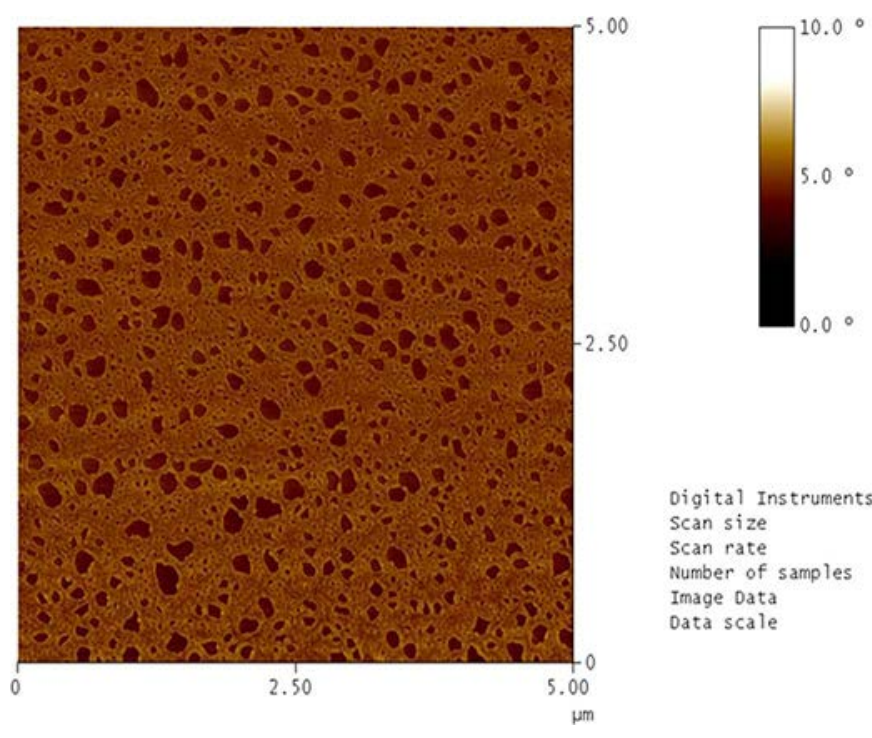

Digital Instruments Nanoscope

Scan size $\quad 5.000 \mu \mathrm{m}$

Scan rate $\quad 1.001 \mathrm{~Hz}$

Number of samples $\$ 12$

Image Data Phase

Figure 12. AFM phase image of DNA dried under $\mathrm{N}_{2}$ flow on mica surface. 

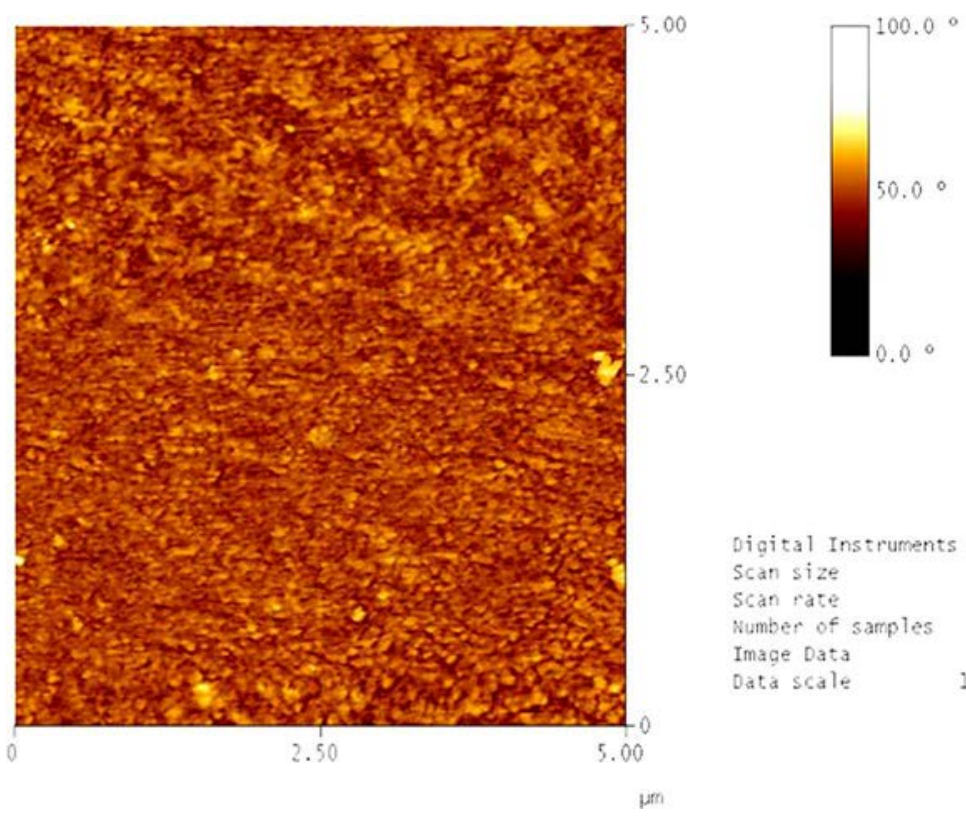

Figure 13. AFM phase image of DNA dried under $\mathrm{N}_{2}$ flow on silica surface.

AFM images of the forced flow $\mathrm{N}_{2}$-dried DNA on mica, silica, and alumina surfaces are shown in Figs. 1214, respectively. Forced flow regime helped in quick drying and compact coverage on mica surface as seen in Fig. 12. DNA dried under $\mathrm{N}_{2}$ flow on mica surface was present in a network structure. The DNA fibers of $0.04 \mu \mathrm{m}$ diameter were all interconnected to each other and $0.14 \pm 0.03 \mu \mathrm{m}$ size empty spaces were placed evenly at $0.26 \pm 0.16 \mu \mathrm{m}$ distance. The DNA dried on silica surface under $\mathrm{N}_{2}$ flow covered the entire surface with particles of $0.05 \pm 0.02 \mu \mathrm{m}$ size as seen in Fig. 13 .
The particles seem as parts of superhelices formed by self-assembly of DNA molecules. DNA dried on alumina surface had interesting agglomerates. There were spherical particles with $1.44 \pm 0.78 \mu \mathrm{m}$ size and rectangular particles of $2.4 \times 0.7$ and $1.6 \times 0.2 \mu \mathrm{m}$ sizes. The particles do not touch each other; they stand separately on the surface of the alumina. Each particle appeared to form from the agglomeration of DNA superhelices.

AFM images of the freeze-dried DNA are seen in Figs. 15-17 for mica, silica, and alumina surfaces, respectively. The vertical distance of DNA on mica,

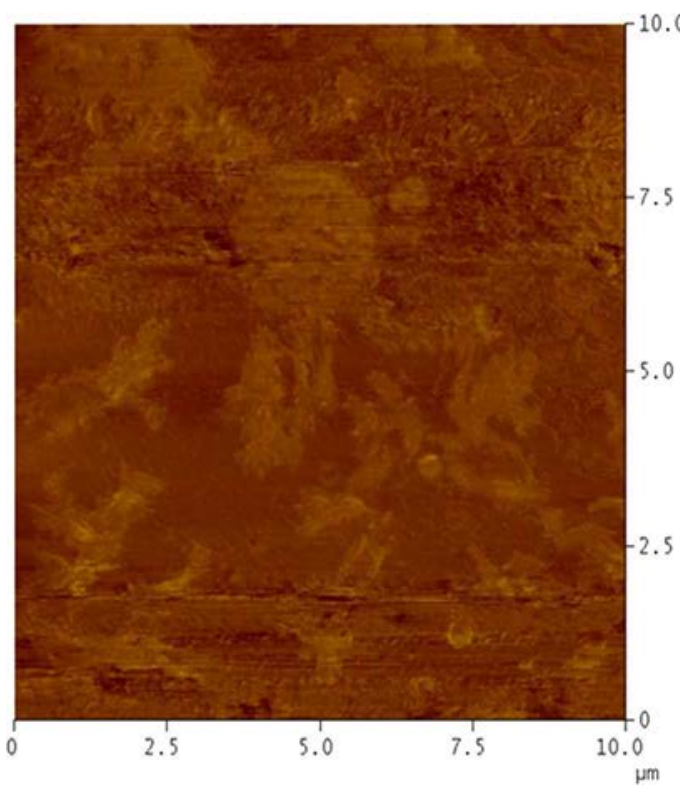

Figure 14. AFM image of DNA dried on alumina surface under $\mathrm{N}_{2}$ flow.

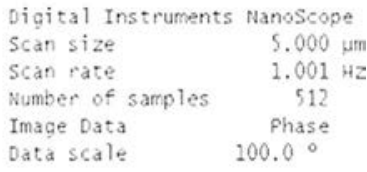



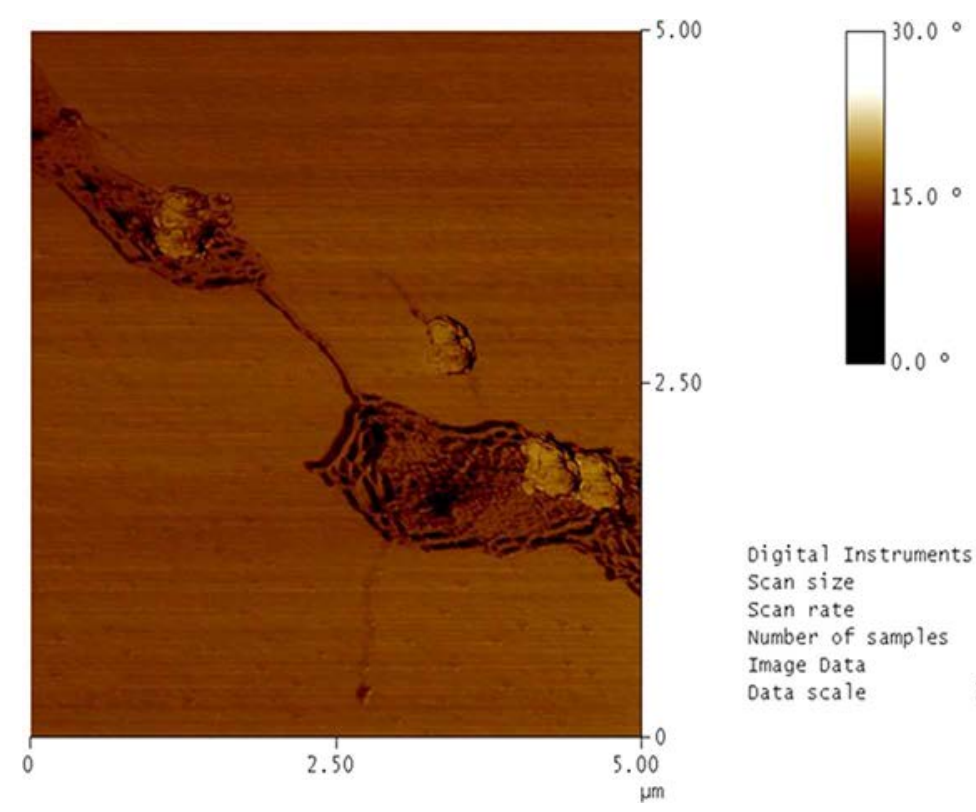

Figure 15. AFM image of DNA after freeze-drying on mica surface.

alumina, and silica surfaces for $\mathrm{N}_{2}$ flow regime was at least 90 domains and their Gaussian distributions are shown in Fig. 18. Freeze-dried DNA showed interesting conformations on mica and silica. The freeze-dried DNA on mica surface had very interesting features as seen in Fig. 15. There are four particles with $0.41 \pm$ $0.03 \mu \mathrm{m}$ size and fibers with $0.04 \mu \mathrm{m}$ diameter folded as $3.1 \times 1.4$ and $0.94 \times 0.94 \mu \mathrm{m}$ islands on the surface of mica. The average end-to-end distance of the superhelices was $2.85 \pm 0.74 \mu \mathrm{m}$ and their average diameter was $0.10 \pm 0.1 \mu \mathrm{m}$. The average pitch of the helices was $0.15 \mu \mathrm{m}$. The particles in spherical form had also a distribution and their average size was $\mu \mathrm{m}$. These fibers were consisted of superhelices from 1,000 to 2,500 DNA molecules. For freeze-dried DNA on mica and silica surfaces, there were no Gaussian distributions. The freeze-dried DNA covered the whole alumina surface as $0.12 \pm 0.03 \mu \mathrm{m}$ particles as seen in Fig. 17 . DNA showed a Gaussian distribution in height on the alumina surface. The average height of DNA on alumina was $4.6 \mathrm{~nm}$ both in normal drying and drying under $\mathrm{N}_{2}$ flow. It is $1.99 \mathrm{~nm}$ for freeze-dried DNA on
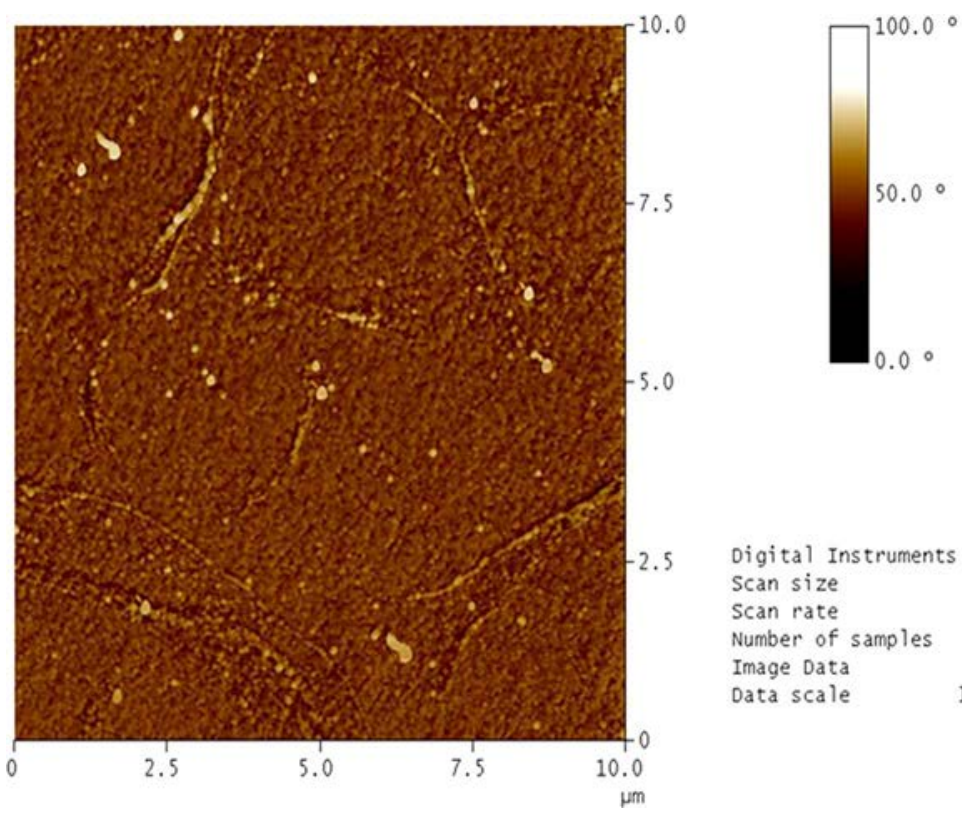

Digital Instruments Nanoscope

Scan size $\quad 10.00 \mu \mathrm{m}$

Scan rate $\quad 1.001 \mathrm{~Hz}$

Number of samples $\quad 512$

Image Data Phase

Data scale $\quad 100.0^{\circ}$

Figure 16. DNA freeze-dried on silica. 


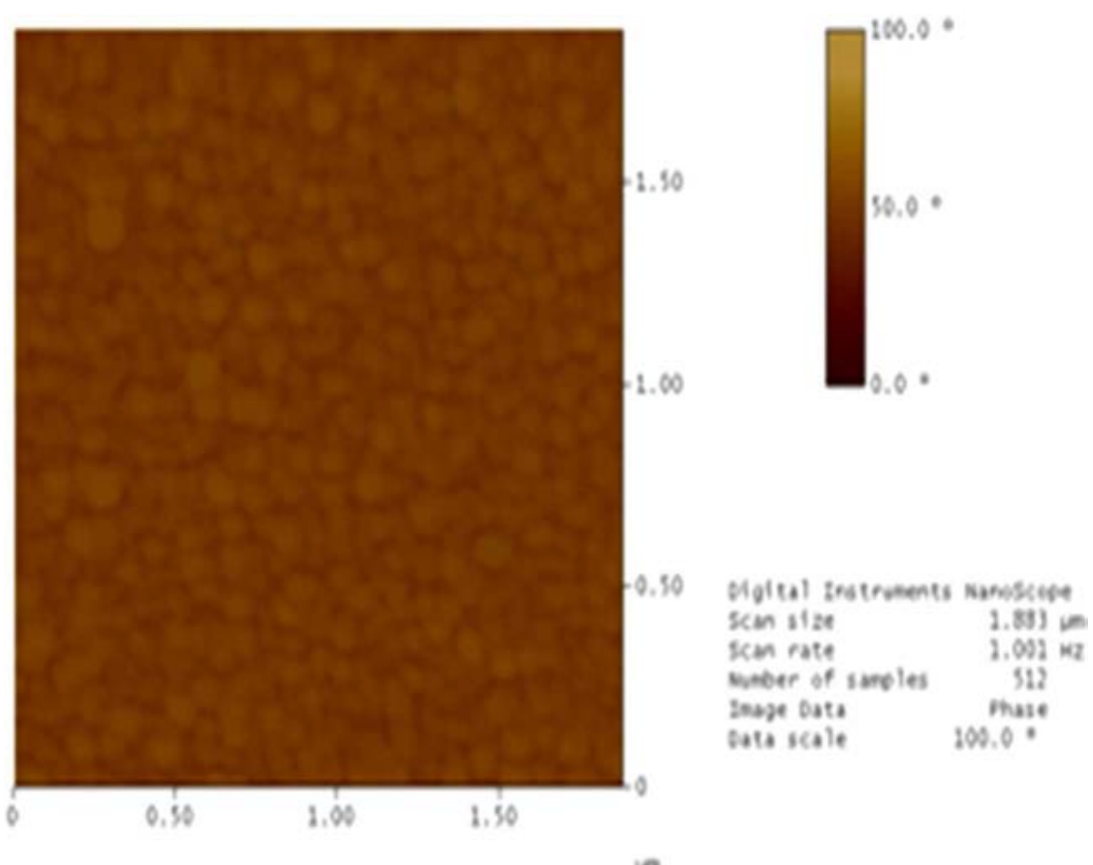

Figure 17. DNA freeze-dried on alumina.

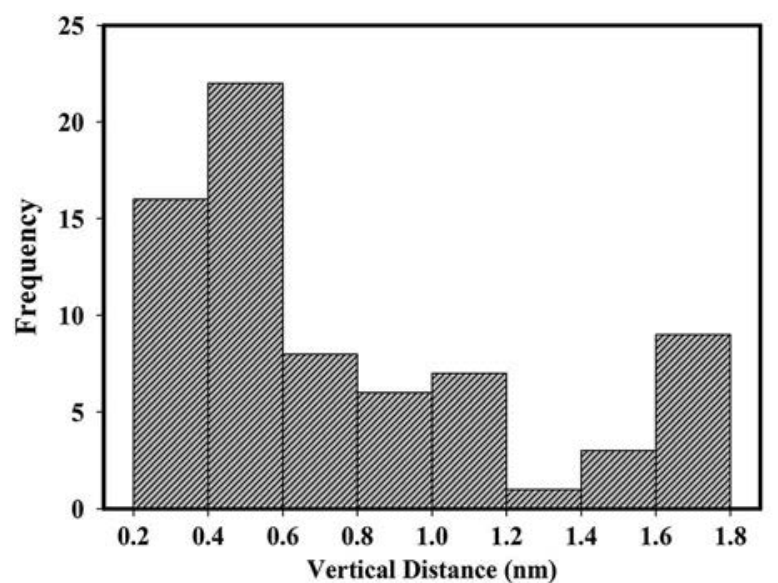

(a)

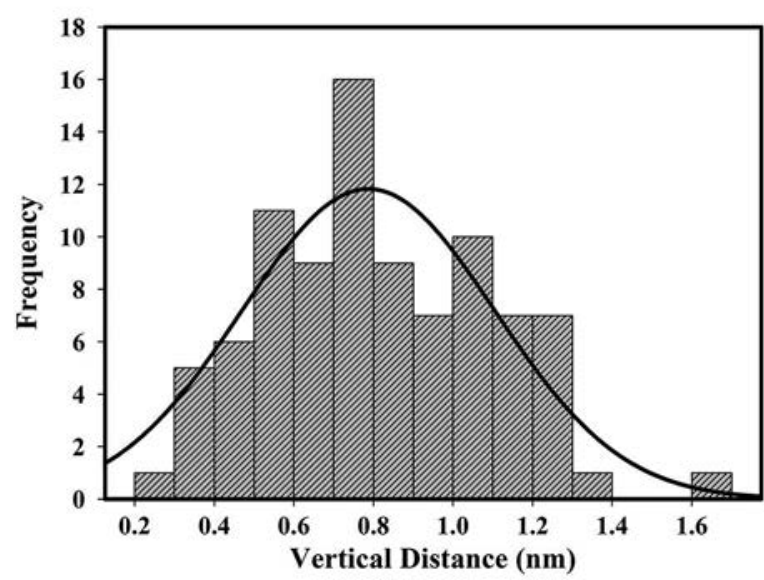

(c)

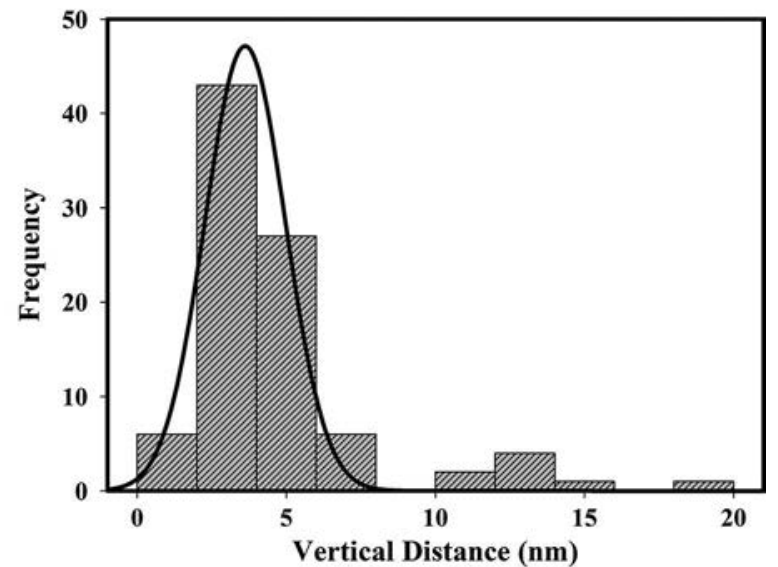

(b)

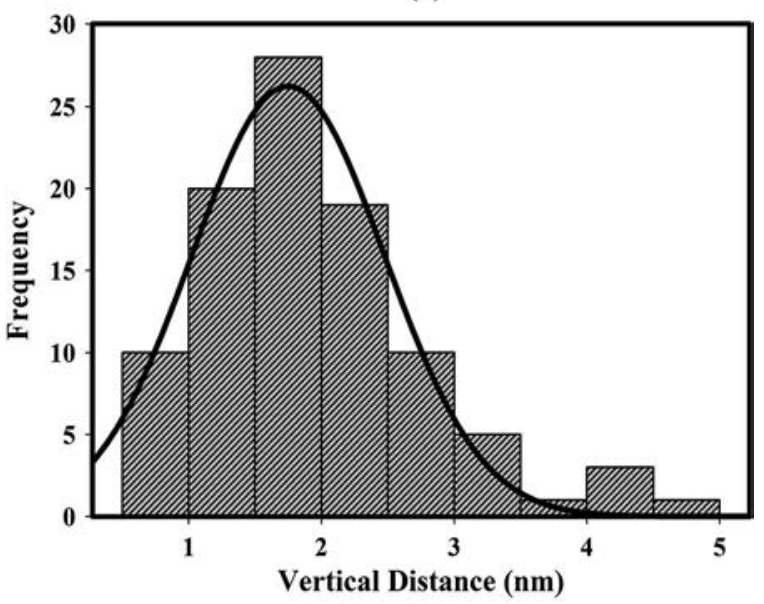

(d)

Figure 18. Vertical distance distribution of DNA under $\mathrm{N}_{2}$ flow regime on (a) mica, (b) alumina, (c) silica surfaces, and (d) by freezedrying on alumina. 
Table 1. Average vertical distance values taken by least 90 domains for different drying method for mica, silica, and alumina surfaces.

\begin{tabular}{|c|c|c|c|c|c|c|c|c|}
\hline \multirow{3}{*}{$\begin{array}{l}\text { Solvent } \\
\text { Substrate (average vertical distance) }\end{array}$} & \multicolumn{4}{|c|}{ Ethanol } & \multicolumn{4}{|c|}{ Water } \\
\hline & \multicolumn{2}{|c|}{ Ambient air } & \multicolumn{2}{|c|}{ Ambient air } & \multicolumn{2}{|c|}{$\mathrm{N}_{2}$ flow } & \multicolumn{2}{|c|}{ Freeze-drying } \\
\hline & Average & $\sigma$ & Average & $\sigma$ & Average & $\sigma$ & Average & $\Sigma$ \\
\hline Mica (nm) & 6.0 & - & 1.4 & 0.1 & 1.6 & 0.1 & Not applicable & Not applicable \\
\hline Silica (nm) & - & - & Not applicable & Not applicable & 0.8 & 0.2 & Not applicable & Not applicable \\
\hline Alumina (nm) & - & - & 4.6 & 0.1 & 4.6 & 0.1 & 1.99 & 0.09 \\
\hline
\end{tabular}

Table 2. The diameter of the particles or supercoils on different surfaces.

\begin{tabular}{lcccc}
\hline Substrate & Ethanol & Ambient air & $\mathrm{N}_{2}$ flow & Freeze-drying \\
\hline Mica $(\mu \mathrm{m})$ & $0.11 \pm 0.03$ & $0.05 \pm 0.04$ & 0.04 & 0.04 \\
Silica $(\mu \mathrm{m})$ & & - & & \\
Alumina $(\mu \mathrm{m})$ & & 0.08 & - & 0.12 \\
\hline
\end{tabular}

alumina. However, DNA dried in air on mica and silica has the average height of 1.6 and $0.8 \mathrm{~nm}$, respectively.

DNA is negatively charged above $\mathrm{pH} 2$. Since silica surface is also negatively charged above $\mathrm{pH} 2$, the adsorption of DNA should be due to hydrogen bonding and van der Waals attractions between silica and DNA. Alumina and DNA had opposite surface charges between $\mathrm{pH} 2$ and 6 , thus ionic attractions play an important role on adsorption on alpha alumina sapphire single crystals. All average vertical distance values belong least 90 domains for different drying method for mica, silica, and alumina.

\section{Discussion}

$\mathrm{N}_{2}$ flow regime was applied to mica, silica, and alumina surfaces. DNA supercoils were present on these surfaces in case of drying by $\mathrm{N}_{2}$ flow. They showed homogenously distributed DNA supercoil structures as shown in Fig. 7. Average vertical distances of least 90 domains were 1.6, 0.8 , and $4.6 \mathrm{~nm}$ for mica, silica, and alumina, respectively, under $\mathrm{N}_{2}$ flow regime. DNA was self-assembled perfectly on silica surface. The average vertical distance of DNA was the same on alumina surface under ambient air and $\mathrm{N}_{2}$ flow drying. However, vertical distance distribution of DNA on alumina surface dried under $\mathrm{N}_{2}$ flow shown in Fig. $18 \mathrm{~b}$ is narrower when compared to Fig. 4 for ambient air-drying on alumina. DNA molecules were not present in water as independent molecules, they formed supercoils by winding on each other. They were further aggregated to different extent both with the drying method and the substrate on which DNA droplet was dried. The diameters of the particles or supercoils on different surfaces are summarized in Table 2.

DNA fibers were dispersed in ethanol and water to obtain homogeneous solutions. The SEM micrographs showed the presence of very long fibers. The helical form of the fibers was not clearly shown by SEM. AFM gave a detailed information about the morphology of the dried DNA from ethanol and water. Different drying techniques on different surfaces allowed us to observe very different morphologies of folded fibers having diameters $0.08-0.12 \mu \mathrm{m}$ as reported in Table 2 . However, heights of the fibers were in $0.1-4.6 \mathrm{~nm}$. The fibers seemed to lay flat on the surfaces indicating stronger attraction of the molecules to the surfaces than to each other.

\section{Conclusion}

DNA solution was dried on mica, silica, and alumina by different drying methods for imaging by AFM. It is indicated that freezing causes the DNA structure become more compact. Freeze-drying is known as the most efficient method for avoiding deconstruction, but conformation of calf thymus DNA was changed. $\mathrm{N}_{2}$ flow regime resulted in a narrower distribution of the vertical distance of highly polymerized calf thymus DNA on mica and alumina surfaces. Nitrogen flow regime did not show significant effect on mica and alumina surfaces except quick drying. Alumina has lower variance values than those of mica and silica surfaces for all methods. The lower average vertical distances (0.1-4.6 nm) and higher diameters (0.08$0.12 \mu \mathrm{m}$ ) of the fibers or particulates on different surfaces showed that the attraction of DNA to surfaces was greater than the intermolecular attractions.

\section{Acknowledgments}

The authors would like to thank the Chemical Engineering Department, Biotechnology and Bioengineering Research and Application Center, Material Research Center of Izmir Institute of Technology. Special thanks to specialist Mine Bahçeci for AFM imaging and Dr. Özlem Çağlar Duvarcı for figure configuration.

\section{References}

[1] Kistner, C.; André, A.; Fischer, T.; Thoma, A.; Janke, C.; Bartels, A.; Gisler, T.; Maret, G.; Dekorsyb, T. Hydration dynamics of oriented DNA films investigated by 
time-domain terahertz spectroscopy. Applied Physics Letters 2007, 90, 233902.

[2] Piskur J.; Rupprecht, A. Aggregated DNA in ethanol solution. Febs Letters 1995, 375(3), 174-178.

[3] Ip, A.C.F.; Tsai, T.H.; Khimji, I.; Huang, J.P.J.; Liu, J. Degradable starch nanoparticle assisted ethanol precipitation of DNA. Carbohydrate Polymers 2014, 110, 354-359.

[4] Arscott, P.G.; Ma, C.; Wenner, J.R.; Bloomfield, V.A. DNA condensation by cobalt hexaammine (III) in alcohol-water mixtures: dielectric constant and other solvent effects. Biopolymers 1995, 36, 345-364.

[5] Paston, S.V.; Zyryanova, I.M.; Zaichikova, Y.V.; Zamotin, V.V. Conformation changes in the DNA molecule caused by $\gamma$ irradiation of its water-ethanol solutions of great ionic strength. Journal of Structural Chemistry 2007, 48(4), 734-739.

[6] Fang, Y.; Spisz, T.S.; Hoh, J.H. Ethanol-induced structural transitions of DNA on mica. Nucleic Acids Research 1999, 2(8), 1943-1949.

[7] Solberg, S.M.; Landry, C.C. Adsorption of DNA into mesoporous silica. The Journal of Physical Chemistry B 2006, 110, 15261-15268.

[8] Jiang X.; X. Lin Atomic force microscopy of DNA self-assembled on a highly oriented pyrolytic graphite electrode surface. Electrochemistry Communications 2004, 6, 873-879.

[9] Leaper, M.C.; Prime D.C.; Taylor, P.M.; Leachet V. Solid bridge formation between spray-dried sodium carbonate particles. Drying Technology 2012, 30(9), 1008-1013.

[10] Pillet, F.; Chopinet, L.; Formosa, C.; Dague, É. Review atomic force microscopy and pharmacology: From microbiology to cancerology. Biochimica et Biophysica Acta 2014, 1840, 1028-1050.

[11] Anselmetti, D.; Luthi, R.; Meyert; E.; Richmond, T.; Dreier, M.; Frommer, J.E.; Guntherodt, H-J. Attractivemode imaging of biological I materials with dynamic force microscopy. Nanotechnology 1994, 5, 87-94.

[12] Bustamante, C.; Keller, D. Scanning force microscopy in biology. Physics Today 1995, 48, 32.

[13] Möller, C.; Allen, M.; Elings, V.; Möller, D.J. Tappingmode atomic force microscopy produces faithful high-resolution images of protein surfaces. Biophysical Journal 1999, 77, 1150-1158.

[14] Paulo, A.S.; Garcia, R. High-resolution imaging of antibodies by tapping-mode atomic force microscopy: Attractive and repulsive tip-sample interaction regimes. Biophysical Journal 2000, 78, 51599-51605.

[15] Hansma, H.G. Surface Biology of DNA by Atomic Force Microscopy. Annu. Rev. Phys. Chem. 2001, 52, 71-92.

[16] Maurice, U.; Mezhericher, M.; Levy, A.; Bordeet, I. Drying of droplet containing insoluble nanoscale particles: Numerical simulations and parametric study. Drying Technology 2013, 31(15), 1790-1807.

[17] Lee, C.; Jang, J.; Hahn, J.W. Theoretical analysis of water droplet drying on different substrates on liquid crystal display panels heated with infrared radiation. Drying Technology 2016, 34(5), 557-562.

[18] Xu, K.; Cao, P.G.; Heath, J.R. Graphene visualizes the first water adlayers on mica at ambient conditions. Science 2010, 329, 1188-1191.

[19] Vandeventer, P.E.; Lin, J.S.; Zwang, T.J.; Nadim, A.; Johal, M.S.; Niemz, A. Multiphasic DNA adsorption to silica surfaces under varying buffer, $\mathrm{pH}$, and ionic strength conditions. The Journal of Physical Chemistry B 2012, 116(19), 5661-5670.

[20] Yelken, G.O.; Polat, M. Determination of electrostatic potential distribution by atomic force microscopy (AFM) on model silica and alumina surfaces in aqueous electrolyte solutions. Applied Surface Science 2014, 301, 149-155.

[21] Adamczyk, Z.; Nattich, M.; Wasilewska, M. Irreversible adsorption of latex particles on fibrinogen covered mica. Adsorption 2010, 16, 259-269.

[22] Hansma, H.G.; Laney, D.E. DNA binding to mica correlates with cationic radius: Assay by atomic force microscopy. Biophysical Journal 1996, 70, 19331939.

[23] Pastre, D.; Pietrement, O.; Zozime, A.; Cam, E.L. Study of the DNA/ethidium bromide interactions on mica surface by atomic force microscope: Influence of the surface friction. Biopolymers 2005, 77, 53-62.

[24] Delain, E.; Fourcade, A.; Poulin, J.C.; Barbin, A.; Coulaud, D.; Cam, E.L.; Paris, E. Comparative observations of biological specimens, especially DNA and filamentous actin molecules in atomic force, tunnelling and electron microscopes. Microscopy Microanalysis Microstructures 1992, 3, 457-470.

[25] Hansma, H.G.; Revenko, I.; Kim Laney, D.E. Atomic force microscopy of long and short double-stranded, single-stranded and triple-stranded nucleic acids. Nucleic Acids Research 1996, 24, 713-720.

[26] Feng, Z.; Jingkun, X.; Shufeng, L. Atomic force microscopy visualization of the DNA network and molecular morphological transition on a mica surface. Thin Solid Films 2008, 516, 7555-7559.

[27] Fang, X.; Li, B.; Petersen, E.; Seo, Y.S.; Samuilov, V.A.; Chen, Y.; Sokolov, J.C.; Shew, C.Y.; Rafailovich, M.H. Drying of DNA droplets. Langmuir 2006, 22(14), 6308-6312.

[28] Majumder, M.; Rendall, C.S.; Eukel, J.A.; Wang, J.Y.L.; Behabtu, N.; Pint, C.L.; Liu, T.; Orbaek, A.W.; Mirri, F.; Nam, J.; Barron, A.R.; Hauge, R.H.; Schmidt, H.K.; Pasquali, M. Overcoming the "coffee-stain" effect by compositional marangoni-flow-assisted drop-drying. Physical Chemistry B 2012, 116, 6536-6542.

[29] Bhushan, B.; Qi, J. Phase contrast imaging of nanocomposites and molecularly thick lubricant films in magnetic media. Nanotechnology 2003, 14, 886-895.

[30] Engel, A. Biological applications of scanning probe microscopes. Annual Review of Biophysics and Biophysical Chemistry 1991, 20, 79-108.

[31] Claussen, I.C.; Ustad, T.S.; Strommen, I.; Walde, P.M. Atmospheric freeze drying-A review. Drying Technology 2007, 25(4-6), 947-957.

[32] Yetgin, S. DNA adsorption on silica, alumina and hydroxyapatite and imaging of DNA by atomic force microscopy. Ph.D. thesis, Izmir Institute of Technology, İzmir, Turkey, 2013.

[33] Yetgin, S.; Balkose, D. Calf thymus DNA characterization and its adsorption on different silica surfaces. Rsc Advances 2015, 5(71), 57950-57959.

[34] Xu, L.; Lio, A.; Hu, J.; Ogletree, D.F.; Salmeron, M. Wetting and capillary phenomena of water on mica. Journal of Physical Chemistry B 1998, 102(3), 540-554. 